\title{
Efficacy of Ayurvedic herbal gel in the management of Dandruff: A case study
}

\author{
Case Report
}

\section{Nilima Dharkar1*, Madhuri Pawar², Vargese Jibi $^{3}$, Asmita Wele ${ }^{4}$}

1. PhD scholar, Department of Rasashastra evum Bhaishajya Kalpana at College of Ayurved, Bharati Vidyapeeth

(Deemed to be University), Katraj, Pune and Professor, Department of Rasashastra evum Bhaishajya kalpana, 3. Professor, Department of Kayachikitsa,

Dr. D. Y. Patil Vidyapeeth deemed to be University, Dr. D. Y. Patil College of Ayurved \& Research centre, Pimpri, Pune. India.

2. Associate Professor and PhD Guide, 4. Professor, Department of Rasashastra evum Bhaishajya Kalpana,

College of Ayurved, Bharati Vidyapeeth (Deemed to be University), Katraj, Pune. India.

\begin{abstract}
Dandruff (Darunak)is the common skin disease affecting the scalp area with the presence of itching, hair fall, dryness of scalp and dander. It is affecting the half of the adult population of either gender worldwide. Even though the prevalence is so high, its etiology being varied the treatment modalities are also different. Although dandruff is not among those disease to cause severe illness or morbidity, but it has a lot of social concern which reflects individual's confidence and self-esteem. This paper aims to present clinical case study presentation with diagnosis using advance technique of Trochoscopy and the management of dandruff with the topical application of Dashemani Kandughna gel which showed excellent results.
\end{abstract}

Key Words: Dandruff (Darunak), Dashemani Kandughna Gel, Trichoscopy.

\section{Introduction}

Health and beauty are collegial with each other; wherein the body mind equilibrium includes balanced digestion, proper tissue formation along with maintenance of skin-hair in normal conditions(1). Maintenance of healthy hair and prevention of the diseases of the scalp, taking care of scalp becomes vital. Every human being desires to remain free from hair problems and keen for healthy hair with healthy scalp.

However due to imbalanced diet, environmental pollutants and improper hair care, individual's scalp may get affected. Dandruff is a scalp disorder which is characterized by excessive shedding of skin cells, itchy-flaky skin and invisible inflammation. Human beings are more prone for occurrence of dandruffat puberty to middle age(2). Dandruff medically described as Pityriasiscaptis caused by Malassezia species(3) which is lipophilic, dimorphic opportunistic yeast causing skinand hair infections(4). Another microorganism community composed of bacteria also inhabits the human scalp and includes facultative naerobic bacteria, such as Propionibacterium acnes and aerobic bacteria, such as Staphylococcus $(3,4)$.

\section{* Corresponding Author:}

\section{Nilima Dharkar}

PhD scholar, Department of Rasashastra evum Bhaishajya Kalpana, College of Ayurved , Bharati

Vidyapeeth( Deemed to be University), Katraj, Pune. India.

Email Id: dharkar.nilima07@gmail.com
Ayurvedic literature reveals that avoidance of oil application and improper cleaning of scalp, sleeping in day time, night vigil, exposure to dust, hot weather are the causative factors for development of dandruff. It is a Vata-kaphajpredominant disease of scalp and producespecific symptoms which are correlated with modern literature of dandruff(5). Moreover it is stated that approximately $50 \%$ adult population is affected by dandruff worldwide while the $18.38 \%$ Indian community is affected by this disorder(6). To combat with occurrence of dandruffand associate symptoms, various antidandruff agents having chemical entities in the form of shampoos, gels, creams etc are utilized in existing current practice. Though these agents have therapeutic potential to treat dandruff like disorders but might be having risk to produce untoward effects to human scalp and hair. Thus innovative dosage form "Dashemani Kandughna gel" is taken as a trial drug . As Dashemani Kandughna mahakashaya is mentioned in the ayurvedic classics(7) is converted into gel form for the ease of the application which is herbal and considerably safe and effective in the management of dandruff.

\section{Case Study}

A 32 year old female presenting with chief complaints of Itching of scalp (Kandu), Hair fall (Keshchyuti)with the presence of Dandruff since 1.6 years. Clinical examination revealed Dryness(Rukshata) and scaling of scalp skin (Twaksputan). Patient was complaining about white flakes fall off from the scalp skin which caused social embarrassment to her. 
No specific past illness and family history present. Patient had Vatakaphajprakruti as analyzed by questionnaires of PrakrutiParikshan. After history taking it was observed that patient was consuming mixed diet with more sour(Amla), salt (lavan) and Pungent (Katu rasa) food.Koshtha was Kruraand irregular bowel habit with feeling of incomplete evacuation. Mutrapravruttiwas 5-6 times/day with normal appearance.Sleeping pattern was disturbed as of 4-5 hours,Sparsh (Touch) was rough and cold. Nadi (Pulse) was $82 / \mathrm{min}$ with Kapha-Vatadoshapradhanya. Jivha (Tongue) was coated. Hair was thick, dark brown in color with dry scalp. Hair wash frequency is weekly once by using chemical shampooswith application of conditioner. Combing habit was only once a day for 2-3 minutes i.e. improper combing. Patient was using chemical medicinal products also. She had been using blow dryer and temporary hair dyes. Scalp hygiene habits showed causative factors for Dandruff.

\section{Ashtavidh Pariksha (8)}

- Nadi (Pulse): 82/min, Regular, Vata-Kaphapradhan

- Druk (Eyes \& Vision):Normal

- Mala (Fecal matter):Krurakoshtha, Irregular bowel habit with feeling of incomplete evacuation

- Aakruti (General Body Built):Madhyam

- Mutra (Urine):Samyak, 6-7 times/day

- Sparsh (Touch):Ruksha (Dry), Sheet (Cold)

- Shabd (Voice of patient): Healthy Normal

- Jivha (Tongue): Sam

Nidan Panchak (9)

- Hetu (Causes): Amla, Lavan, Katu rasa sevan, Disturbed sleeping pattern, Scalp hyginehabbits, Combing habbits, Use of Chemical products, blow dryer and temporary dyes.

- Roop (Signs): Scalp Itching, Hair fall, White flakes falling off from scalp

- Upshaya (Examination Method): Scalp status was examined by subjective and objective parameters.

Subjective parameters included Itching (Kandu) - 03, Falling of Hair (KeshaChyuti) - 03, Dryness (Rukshata) - 03 and Scaling / cracking of skin (Twaksputan)-03.

$0,1,2,3$ were the gradation according severity of symptoms(10).

\begin{tabular}{|c|c|}
\hline Grade & Severity \\
\hline \multicolumn{2}{|c|}{ Itching (Kandu) } \\
\hline 0 & No itching \\
\hline 1 & Mild, Tolerable ( 1 to 2 times a day) \\
\hline 2 & Moderate, Intolerable ( 3 to 4 times a day) \\
\hline 3 & Severe, Intolerable ( 5 to 8 times a day) \\
\hline \multicolumn{2}{|c|}{ Falling of Hair (KeshaChyuti) } \\
\hline 0 & 1 to 5 Hair fall on combing /washing \\
\hline 1 & Mild ; Less than 20 Hair fall on combing /washing \\
\hline 2 & Moderate; more than 20 hair fall on combing / washing \\
\hline 3 & Severe ; Less than 20 hair fall on simple hand strength \\
\hline
\end{tabular}

\section{Dryness ( Rookshata) \\ 0 No Dryness \\ 1 Mild; Dryness with rough skin \\ 2 Moderate; Dryness with scaling \\ 3 Severe; Dryness with cracking skin \\ Scaling/ Cracking of skin (Twaksputan) \\ $0 \quad$ No scaling \\ 1 Mild; Scaling 1/4th part usually on vertex \\ 2 Moderate; Scaling is more than $1 / 2$ part \\ 3 Severe; complete Scaling}

Objective parameters included Trichoscopy(11)

$0 \quad$ No scales

1 Thin scales

2 Diffused thin scales

3 Thick heaped-up scales but not forming plaques

4 Diffused thick heaped-up scales but not forming plaques

5 Very thick heaped-up scales forming plaques

Four zones on each patient's scalp was predefined for assessment -Fontal, Right / left parietal, Right / Left Temporal, Occipital. Comb was used to part the hair in each area to give a clear view of the patient scalp. Each section of the scalp was assessed for the presence of dandruff flakes. 0 means no flakes and 5 means intense flaking.

\section{Samprapti (5) (Pathogenesis):}

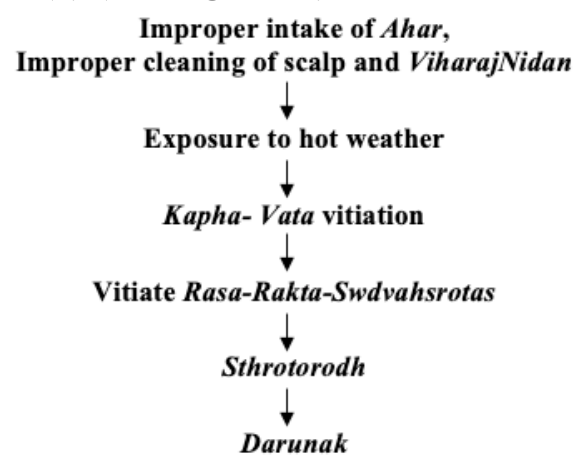

Samprapti Ghatak (5)

- Dosha: Kapha, Vata

- Dushya:Twak, Rakta

- Srotas: Swadvahsrotas

- Adhishthan :Kapal(Scalp)

- Vyaktisthan: Kapal(Scalp)

- Differential diagnosis: Seborrheic dermatitis

\section{Treatment}

- Dashemani Kandughna gel - Topical application on scalp at night (Nishakal)(12)daily for 21 days.

In Ayurvedic classical text the application of Hair pack (lepa) formulation for treatment of Dandruff (Darunak) is stated, wherein 21 days application is recommended to get desired effect. Thus in present study Dashemani Kandughna Gel was topically applied for continuous 21 days with gentle massage on scalp skin. Skin protective barrier function is decreased during the night hours and there is more permeability. Thus,Dashemani Kandughna Gel was applied at nighttime for better absorption and better efficacy. 
International Journal of Ayurvedic Medicine, Vol 12 (4), 975-980

\section{Preparation of Dashemani Kandughna Gel:}

Table 1: Dashemani Kandughna Gel Ingredients

\begin{tabular}{|c|c|c|c|c|}
\hline S. $\mathbf{N}$. & $\begin{array}{l}\text { Drug Name \& } \\
\text { Part Used }\end{array}$ & Latin name & Quantity & Action \\
\hline 1 & $\begin{array}{l}\text { Raktachanda } \\
\text { Stem }\end{array}$ & $\begin{array}{l}\text { Pterocarpus santalinus Linn. } \\
\text { Family: Leguminosae }\end{array}$ & $25 \mathrm{~g}$ & $\begin{array}{l}\text { Antimicrobial to Staphylococus aureus \& } \\
\text { Pseudmonus aeruginosa (13) }\end{array}$ \\
\hline 2 & $\begin{array}{l}\text { Jatamansi } \\
\text { Root }\end{array}$ & $\begin{array}{l}\text { Nordostachys jatamansi DC } \\
\text { Family: Valerianaceae }\end{array}$ & $25 \mathrm{~g}$ & Inhibition to Staphylococcus aureus (14) \\
\hline 3 & $\begin{array}{l}\text { Aaraghwadh } \\
\text { Leaves }\end{array}$ & $\begin{array}{l}\text { Cassia fistula Linn. } \\
\text { Family: Caesalpinioidae }\end{array}$ & $25 \mathrm{~g}$ & $\begin{array}{l}\text { Antimicrobial to Staphylococcus aureus\& } \\
\text { staphylococcus epidermidis (15) }\end{array}$ \\
\hline 4 & $\begin{array}{l}\text { Karanj } \\
\text { Seed }\end{array}$ & $\begin{array}{l}\text { Pongamia pinnata Pierre } \\
\text { Family: Leguminosae }\end{array}$ & $25 \mathrm{~g}$ & $\begin{array}{l}\text { Antimicrobial activity to Staphylococcus aureus } \\
\text { (16) }\end{array}$ \\
\hline 5 & \begin{tabular}{|l|} 
Nimb \\
Leaves
\end{tabular} & $\begin{array}{l}\text { Azadiracta indicia.Juss } \\
\text { Family: Meliaceae }\end{array}$ & $25 \mathrm{~g}$ & Antiseptic, antifungal \& Carminative action \\
\hline 6 & $\begin{array}{l}\text { Kutaj } \\
\text { Bark }\end{array}$ & $\begin{array}{l}\text { Holarrhena } \\
\text { antidisynterica(Linn)Wall) } \\
\text { Family: Apocynaceae }\end{array}$ & $25 \mathrm{~g}$ & $\begin{array}{l}\text { Antimicrobial action against Psedomonas } \\
\text { aurengosa (17) }\end{array}$ \\
\hline 7 & $\begin{array}{l}\text { Sarshap } \\
\text { Seed }\end{array}$ & $\begin{array}{l}\text { Brassica campestris Linn. } \\
\text { Var.Sarson Prain } \\
\text { Family Cruciferae }\end{array}$ & $25 \mathrm{~g}$ & Vermifuge,cures skin eruptions \& itching (18) \\
\hline 8 & $\begin{array}{l}\text { Yashtimadhu } \\
\text { stem }\end{array}$ & $\begin{array}{l}\text { Glycerrhiza glabra Linn. } \\
\text { Family: Leguminosae }\end{array}$ & $25 \mathrm{~g}$ & Anti-micotic action against Candida (19) \\
\hline 9 & $\begin{array}{l}\text { Daruharidra } \\
\text { Stem }\end{array}$ & $\begin{array}{l}\text { Berberis aristata DC } \\
\text { Family: Berberidaceae }\end{array}$ & $25 \mathrm{~g}$ & $\begin{array}{l}\text { Antibacterial to Staphylococcus aureus, anti- } \\
\text { helminthic and leishmanicidal properties (20) }\end{array}$ \\
\hline 10 & $\begin{array}{l}\text { Musta } \\
\text { Rhizome }\end{array}$ & $\begin{array}{l}\text { Cyprus rotundus Linn } \\
\text { Family: Cyperaceae }\end{array}$ & $25 \mathrm{~g}$ & Antibacterial \& antifungal action(21) \\
\hline 11 & Carbopol 934 & Carbomer & $10 \mathrm{~g}$ & Gelling agent(22) \\
\hline 12 & Triethaloamine & & q.s. & $\mathrm{pH}$ adjuster (22) \\
\hline 13 & Glycerol & & $30 \mathrm{~g}$ & Humectants \\
\hline 14 & $\begin{array}{l}\text { DMDM } \\
\text { (1,2 Dimethylol-5,5 } \\
\text { dimethylhyda ntoine) }\end{array}$ & & $6 \mathrm{~g}$ & Preservative (23) \\
\hline
\end{tabular}

Authentication and identification of herbal drugs were conducted at Agharkar research institute Pune . All herbal drugs were subjected to various physico-chemical testsas per API. Analytical reagents grade gelling agent, $\mathrm{pH}$ adjuster and preservative were taken.

Dashemani Kandughna gel was prepared by standard method of gel preparation

Preparation of Dashemani Kandughna gana coarse powder:

All the drugs of Dashemani Kandughna gana each $25 \mathrm{~g}$ were taken in dry form. They all were minced in pulveriser one by one with 36 number sieve to get coarse powder and then all powders blend in hexagonal mass mixture machine to get homogeneous mixture.

Preparation of Dashemani Kandughna gana decoction (24):

One part(250 g) Dashemani Kandughna gana coarse powder was taken in stainless steel vessel. Sixteen times $(4000 \mathrm{ml})$ water was added in it and it was heated at medium flame till its $1 / 4^{\text {th }} \quad \mathrm{p} \mathrm{a} \mathrm{r} \mathrm{t}$ $(1000 \mathrm{ml})$ was remained. Then it was filtered with muslin cloth to acquire decoction.

Preparation of Dashemani Kandughna gel(25):

Dashemani Kandughna decoction(1000 ml)of normal temperature was taken. Then added Carbopol $934 \mathrm{P}$ of $1 \%$ concentration $(10 \mathrm{~g})$ with the addition of
Glycerol (30 g) \& DMDM (6 g). The mixture was kept for 6-7 hours to allow the dispersion of Carbopol. After thatwith the aid of overhead mechanical stirrer, make a homogeneous mixture with $1200 \mathrm{rpm}$ to form gel aspect.Obtained homogeneous mixture was neutralized with required quantity of Triethanolamine drop by drop with continuous stirring until it gets converted into perfect desired gel and $\mathrm{pH}$.

\section{Physico-analytical testing}

This prepared gel was analysed as follows:

- Colour-Yellowish Brown,

- Odor-Pleasant,

- State- Semisolid,

- Visual appearance- Translucent and Transparent,

- Homogeneity- Consistent,

- $\mathrm{pH}-6.98$,

- Viscosity at $20 \mathrm{rpm} 34,500$, at $100 \mathrm{rpm}-9450$,

- Spreadability- Easily Spreadable,

- Irritancy test- No Redness, No oedema, No inflammation and Irritation during Irritancy test,

- TLC- Tannin-0.47, Flavonides-0.84 and Saponins-0.64.

\section{Material and Methods}

\section{Homogeneity (26)}

Gel was tested by pressing a small amount of gel between the index finger and thumb. The gel's consistency, presence of coarse particles, if any, was used to evaluate the texture and homogeneity of gel. 
Nilima Dharkar et.al., Efficacy of Ayurvedic Herbal gel in the management of Dandruff: A case study

pH determination (26)

$\mathrm{pH}$ of Gel was performed by using Digital $\mathrm{pH}$ meter previously calibrated before each use with standard buffer solutions.

\section{Viscosity (27)}

Viscosity of gel was determined by using Brookfield Viscometer at 20 RPM and at 100 RPM DVII+Pro with $\mathrm{T}$ bar spindle and Helipath adjustment. The suitable $\mathrm{T}$ bar spindle was selected to obtain torque value between 10 to 100 . The viscosity of gel displayed on screen at $25^{\circ} \mathrm{C}$ was recorded.

\section{Spreadability (28)}

Both glass slides of apparatus were cleaned with alcohol and allowed to dry. $1 \mathrm{~g}$ of gel was placed between the two glass slides. Then $100 \mathrm{~g}$ of weight was placed on top slide for 5 minutes to compress the sample up to uniform thickness. Initial weight $(100 \mathrm{~g})$ was added in the pan. The weight in the pan was increased until the upward slide starts to move over stationary slide. The time in seconds(s) require to separate the two slides was noted. The triplicate of each sample was taken and time required and distance travelled by slide was noted.

\section{Irritancy test(29)}

Mark an area of one square $\mathrm{cm}$ on the left hand dorsal surface. The Sample gel was applied to the specified area and time was noted. Irritancy, erythema, oedema was checked, if any, for regular intervals up to 24 hours and reported.

\section{Thin Layer Chromatography(30)}

$1.0001 \mathrm{~g}$ of gel was taken \& dissolved in $10 \mathrm{ml}$ of methanol. ( $1 \%$ solution). After the preparation of mobile phase \& test solution TLC plate (TLC silica Gel 60F 254) were taken. Then 1 drop added at the downward center of TLC plate with the help of capillary tube. Measure the distance of $2 \mathrm{~cm}$ from downward. Then TLC plate kept in TLC chamber until solution is running at $1 / 4$ th portion. After running the solution, TLC Plate was taken out of the chamber. TLC plate was allowed to air dry. The air dried plate was placed in UV cabinet at $365 \mathrm{~nm}$ (make Biotechnics India, ID No. 71649). Then Purple colored observed for Tannis, $\mathrm{R}_{\mathrm{f}}$ Calculated. Same method shall be applicable for Saponins and Flavonoids. Mobile phase for Saponins-Chloroform: Methanol: Water (70:30:4) Mobile phase for Flavonoides: Chloroform: Ethyl Acetate $(60: 40)$ and for Tannin Chloroform: Methanol: Acetic Acid (18:1:1).

\section{Results}

After the 7 th, 14 th and $22^{\text {nd }}$ day of assessment, variations in results were found on each symptom associated with Dandruff (Darunak). Patients got relief in sign and symptoms with gradual improvement. Assessment on each symptom of Dandruff and Trichoscopy examination have been presented in Table no. 1 and 2.

\begin{tabular}{|c|c|c|c|c|c|}
\hline \multirow{2}{*}{$\begin{array}{l}\mathrm{Sr} \\
\text { No }\end{array}$} & \multirow{2}{*}{ Symptoms } & \multirow{2}{*}{$\begin{array}{c}\text { Before } \\
\text { Treatment }\end{array}$} & \multicolumn{3}{|c|}{ After Treatment } \\
\hline & & & 7th Day & 14th Day & 22nd Day \\
\hline 1 & Itching & 3 & 1 & 1 & 0 \\
\hline 2 & Falling of Hair & 3 & 2 & 2 & 1 \\
\hline 3 & Dryness & 3 & 2 & 1 & 0 \\
\hline 4 & $\begin{array}{c}\text { Scaling / } \\
\text { Cracking of skin }\end{array}$ & 3 & 2 & 1 & 0 \\
\hline 5 & $\begin{array}{l}\text { Other symptoms } \\
\text { if any }\end{array}$ & & & & \\
\hline & $\begin{array}{l}\text { A. Irritation } \\
\text { B. Inflammatior } \\
\text { C. Redness } \\
\text { D. Exaggerated } \\
\text { symptoms of sca }\end{array}$ & & No any & No any & No any \\
\hline
\end{tabular}

Table 2: Trichoscopy Report

\begin{tabular}{c|c|c} 
Trichoscopy & Before Treatment & After Treatment \\
Finding Grade & 5 & 1
\end{tabular}

Before Treatment: Trichoscopy of four zones

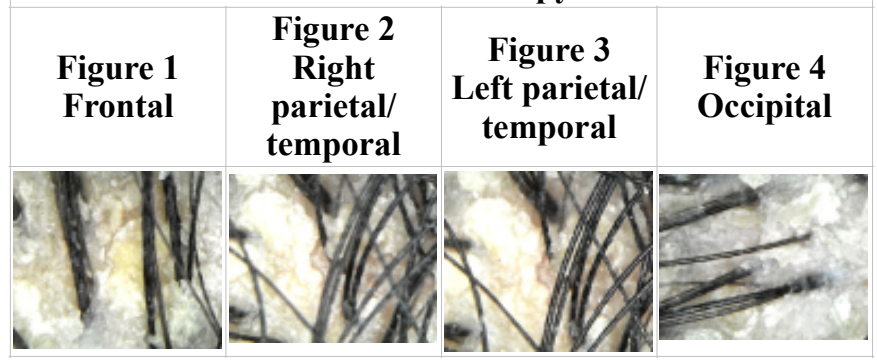

After Treatment: Trichoscopy of four zones

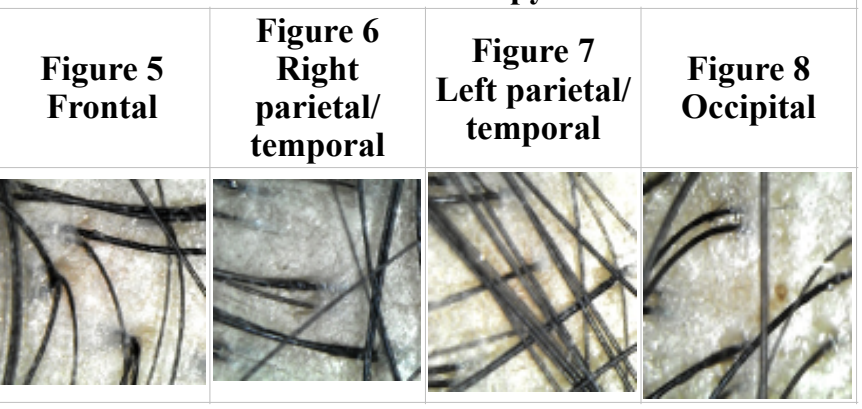

\section{Discussion}

Darunak can be corelate with Dandruff which is a common scalp disorder, characterized by presence of corneocytes that form clusters due to their high cohesive power, in the form of flaky white to yellowish scales with dryness of scalp, accompanied by itching and hair fall(31). Stringent ayurvedic literature review revealed that there are different diseased condition stated under Kshudrarog or Shirorogadhikar(32). Causing factors for darunak are intake of improper Aharadravya, improper cleaning of scalp and Viharajnidan like Rajahasavana (Exposure to dust), Atapaathisevana (Exposure to hot weather). Due to this Kapha,Vatavitiation occurs which further vitiates RasaRaktadhatu resulting in vitiation of Rasa- RaktaSvedavahastrotus.It is subsequent the strotorodha ensuing the Darunak (Dandruff)(5). Microorganisms like Malassezia species, Propionibacterium and Staphylococcus are also causing factors of Dandruff $(3,4)$. 
Thus considering this guideline of ayurvedic classical text, in the present study Dashemani kandughna gel encloses herbal drugs viz Raktachandan, Jatamansi, Araghwadh, Naktamal( Karanj), Nimb, Kutaj, Sarshap, Yashtimadhu, Daruharidra and Musta are selected as all these drugs possesses anti-Itching (Kandughna), antibacterial (Krumighna), reduce inflammation (Shothghna), Wound healing (Vranaropan) and antimicrobial( Kushthghna) action( 33).

It is observed that all drugs are useful in skin related problems with symptoms of itching, infection, inflammation and pain. Cumulative action in combination of ten herbal drugs of Dashemani Kandughna gel showed excellent results on pacifying the vitiated Dosha-Dushya affecting the scalp skin reduces dandruff. All these herbal drugs are advised to treat Kandu (Itching) like symptom occurred due to certain changes in physiological conditions(7). In earlier research work it is also reported that stem of Raktachandan has antimicrobial activity to Staphylococcus aureus and Psedomonus aeruginosa (13), root of Jatamansi showed significant inhibition to Staphylococcus aureus(14), Araghwadh leaves having antimicrobial activity to Staphylococcus aureus and Staphylococcus epidermis(15), the seeds of Karanj comprise antibacterial (Staphylococcus aureus) activity(16), leaves of Nimb has antiseptic, antifungal and carminative actions as well as Sarshap is effective as vermifuge(17), to cure skin eruption and itching. Kutaj bark has antimicrobial activity against Pseudomonus aerunginosa(18), Yashtimadhu has reported ant micotic activity against Candida albicans (19). Daruharidra possesses antibacterial, antihelminthic and leishmanicidal activity as against Candida albicans and considered as anthelmintic to cure skin rashes and wounds (20). Thus synergism of all these ten herbal drugs showed therapeutic potential to treat flaky, itchy skin as present in dandruff.Dashemani Kandughna gel helps to clean off the debris and prevent the scalp from secondary incursion of microbial growth by giving promising results.

\section{Conclusion}

Vata-Kaphaj predominance and microbial growth of specific species causes Dandruff. In this case report new innovative dosage form "Dashemani kandughna gel" was found safe and showed excellent results in the management of Dandruff. The treatment was focused to relieve the signs and symptoms of the disease, ameliorating the associated complains and maintaining the effect of the gel for a long term. The standardization and stability study of Dashemani kandughna gel was also conducted.

\section{Acknowledgement}

The authors acknowledge the immense help received from the scholars whose articles are cited and included in references of this manuscript. The authors are also grateful to authors/editors/ publishers of all those articles, journal and books from where the literature for this article has been reviewed and discussed.Also greatful to College of Ayurved, BharatiVidyapeeth , Pune and Dr.D.Y.Patil College of Ayurved, Pimpri - Pune for the resources provided.

\section{Reference}

1. https://www.mapi.com/ayurvvedic-knowledge/ ayurvedic-beauty/ayurvedic-perspective-onbeauty.html dated 10.08.2021 time 11.10

2. Elewski BE. Clinical diagnosis of common scalp disorders.J Investing Dermatol Symp Proc. December,2005;10(3):190-3

3. Grice, E. A., Segre, J. A. The skin microbiome. Nat Rev Microbiol.March,2011; 9:244-253

4. Findley, K. et al.,Serge ,J. Topographic diversity of fungal and bacterial communities in human skin. Nature .May2013;498:367-370

5. Hiremuth.A clinical study of Gunja Tail shirobhyang in the managementof . Darunak, Dissertation of Rajiv Gandhi University of Health Sciences, Karnataka, Banglore, 2006.

6. Piérard-Franchimont C, Xhauflaire-Uhoda E, Piérard GE. Revisiting dandruff.Int J Cosmet Sci. October 2006; 28(5):311-318

7. Chakrapanidatta. Charak Samhita.Chaukhamba Surbharati PrakashanVaranasi; Reprint 2000.33p.

8. Tekade A, Watkar, Daulatkar K, Dive M. Review of Ashtavidh Parikasha w. s. r. to Nadipariksha. International Journal of Ayurveda and Pharma Research.January2018; 6(1);40-43

9. Thakur A, Srivastav A, Manglesh R. A Review article on importance of Nidan Panchak in Ayurveda. International Journal of Pharmacy and Analytical research. September 2018; 7(3); 399-402

10. Naik V.K. Study On Efficacy Of Gunja Taila Shiroabhyanga And Nimba Twak Churn in the management of Darunak. International Journal of Ayurveda nand Pharma research.December 2016 ; 4 (12); $15-20$

11. Bhattacharyya A, Jain N, Sengupta S. Evaluation of therapeutic potential of VB-001, a leave-on formulation for the treatment of moderate adherent dandruff. BMC Dermatology May 2017; $17(5) ; 1-9$

12. https://blog.reneerouleau.com dated 16/08/2021 time14:15 IST

13. Manjunath. Antimicribial activity of Pterocarpus Santalinus.India J, Pharm. Sci.Jan-Feb 2006;68(1);115-116

14. Parveen Z. Volatile constituents, antibacterial and antioxidant activities of essential oil from Nardostachys jatamansi. Pharmacologyonline. Jan 2011; 3; 329-337

15. Panda K. Antibacterial activities and analysis of Cassia fistula (Linn)leaf. Journal of advanced Pharmaceutical Technology and Research. JanMar2011;2(1);62-67

16. Ujwal P. Antimicrobial activity of different extracts of PongamiaPinnata, Medicinal and .Aromatic 

plants Science and Biotechnology. Global science book. 2007; 1(2); 285-287

17. Srivastava N, SaxenaV. Antibacterial activity of Kutaj (Holarrhenaanti- dysenterica Linn.) in childhood diarrhea - In vitro study.ThePharma innovationjournal.2015;4(4);97-99

18. Kirtikar K R, Basu B.D. Indian Medicinal plants. International Book Distributer Deharadun. $2^{\text {nd }}$ ed,Vol1. 1999;165, 539p.

19. Korhalkar A, Deshpande M, Lele P, Meera M. Antimicrobial activity of Yashtimadhu (Glycyrrhiza glabra L.) - A Review. IJCMAS. November 2014; 3(1); 329-336

20. Saxena S, Negi R, Guleri S .Antimicrobial potential of BerberisaristataDC.against some human bacterial pathogens. Journal of Mycopathological Research. October 2014;52(2);227-235

21. Singh V. Analysis and antimicrobial activity of the essential oil of CyperusrotundusL.rhizomes. Journal of Medicinal Plants Studies 2018; 6(5);101-105

22. h t p s:// w w w c h e mi c albook. com/ ChemicalProductProperty_EN_CB9852620.htm dated 17-08-2021 time 15:10 IST

23. https://www.chemicalsafetyfacts.org/dmdmhydantoin-2 dated 18-08-2021 time 11.15 IST

24. Sastri P. Sharandhar Samhita, Madhyam Kahand. $5^{\text {th }}$ ed. Varanasi; Chaukhamba Prakashan; 2002.144p.

25. Remington. The science and Practice of Pharmacy, Part I.22 $2^{\text {nd }}$ ed. Published in the $191^{\text {st }}$ year of the Philadelphia College of Pharmacy,
Pharmaceutical Dosage form:Manufacturing and Compounding. 1995. 83p.

26. MeiX Chen,Kenneth S.A,Baki G.Formulation and evaluation of antibacterial creams aand gels containing metal ions for topical application. Journal of pharmaceutics. October2016; 1-10

27. Lieberman H.A., Rieger M.M., Banker G.S. Pharmaceutical Dosage Forms : Disperse . systems, Vol 2.2 $2^{\text {nd }}$ ed.New York; Inform healthcare; 2008. 403p.

28. Rigo L.A., Weber J.,Silva C., Beck R.C. Evaluation of spreadability of pharmaceutical or cosmetic semisolid formulations using scanned images. Latin American Journal of Pharmacy. December 2012; 31(10); 1387-1391

29. Chauhan L, Gupta S. Creams: A review on classification, preparation methods, evaluation . and its applications. Journal of Drug Delivery and Therapeutics. Oct 2020; 10(5); 281- 289

30. Government of India. Ministry of Health and Family welfare. Dept of ISM and $H$. The Ayurvedic Pharmacopia of India Part I Volume II. $1^{\text {st }}$ ed. Delhi; 1999. Controller of Publication; 195-196p.

31. Elewski B E.Clinical diagnosis of common scalp disorders. J Investing Dermatol Symp Proc. Dec 2005; 10(3); 190-193

32. Ambikadatta Shastri. Bhaishjya Ratnavali.15ed. Varanasi; Chaukhamba Sanskrit Sansthan; 2002. $624 \mathrm{p}$.

33. Priyavat Sharma. Dravyaguna Vigyana Part II.2ed.Varanasi; Chaukhamba Bharati Academy; 2018. 716,31,170,144,149,463,152,253,537,370p. 